rature in each trial : trial 1 , at $12{ }^{\circ} \mathrm{C}, 2600,2300$ and $1975 \mathrm{~g} /$ day ; at $20^{\circ} \mathrm{C}, 2510,2300$ and $2000 \mathrm{~g} / \mathrm{d}$; trial 2 , at $20^{\circ} \mathrm{C}, 2530,2230$ and $1900 \mathrm{~g} / \mathrm{d}$; at $28^{\circ} \mathrm{C}, 2200,1900$ and $1600 \mathrm{~g} / \mathrm{d}$. The diet based on maize and soyabean meal included $3.3 \mathrm{Kcal} \mathrm{DE} / \mathrm{g}$.

The temperature $\times$ level of feed intake interaction was not significant for any of the criteria considered. Growth rate increased linearly $(P<0.01)$ with the amount of feed intake. At 12 and $20^{\circ} \mathrm{C}$ (trial 1) reduction of the feeding level by $1 \mathrm{~g} / \mathrm{d}$ was accompanied by a decrease in the growth rate of $0.37 \pm 0.05 \mathrm{~g} / \mathrm{d}$; at 20 and $28{ }^{\circ} \mathrm{C}$, the corresponding value was $0.39 \pm 0.02 \mathrm{~g} / \mathrm{d}$. With the same feeding level, a $1{ }^{\circ} \mathrm{C}$ reduction of room temperature in the $28-20$ " $\mathrm{C}$ interval caused a lowering of weight gain of $6 \mathrm{~g} / \mathrm{d}$, on an average ; between 20 and 12 " $\mathrm{C}$ the corresponding value was $14.3 \mathrm{~g} / \mathrm{d}$. Feed conversion ratio increased with a reduction of room temperature of 0.14 unit $(P<0.05)$ between 28 and $20^{\circ} \mathrm{C}$ and of $0.39(\mathrm{P}<0.01)$ between 20 and 12 " $\mathrm{C}$. The same growth rates were obtained at 20 and $28^{\circ} \mathrm{C}$ and at 12 and $20^{\circ} \mathrm{C}$ by a supplementary dietary supply of 16 and $38 \mathrm{~g} / \mathrm{d}$ by degree of reduction of the room temperature in the $28-20$ and $20-12$ intervals, respectively.

The decrease in feeding level led to a linear increase $(P<0.01)$ in the loin/backfat ratio and muscle percentage and to a linear decrease $(P<0.01)$ in the carcass fat percentage. With the same level of feed intake, there was no difference in the fattening performance between animals kept at 20 and $28^{\circ} \mathrm{C}$. At $12^{\circ} \mathrm{C}$, carcass adiposity estimated by the loin/backfat ratio and the muscle percentage was lower $(P<0.05)$ than at $20^{\circ} \mathrm{C}$.

All these results suggest that the effect of low temperatures on fattening performance is similar to that of restricted feeding and that a high temperature $\left(>20^{\circ} \mathrm{C}\right)$ may lead to feed sparing.

\title{
Testing of two ways of keeping up a minimal rate of ventilation in a fattening house
}

\author{
R. GRANIER *, B. DE LA FARGE ** \\ Institut Technique du Porc \\ * Station Expérimentale, Les Cabrières, 12200 Villefranche-du-Rouergue \\ ** Région Sud, 34, boulevard de la Gare, 31500 Toulouse
}

Two different ways of keeping up animal rate of ventilation were tested in fattening houses. Maintaining such a rate is a technological problem, the practical rate being often too high. Our aim being that the indoor ventilation system provides a variation ranging from ten to hundred percent, we designed two different simple apparatuses : one with fans running and stopping in turn while on minimal rate and the other with fans running steadily while providing a specific mixture of fresh and indoor air so that the rate of fresh air should be equivalent to the chosen minimal rate.

Two different trials at different seasons were performed on both techniques in two different fattening houses containing 80 pigs. The animals displayed no significant differences of their growing characteristics in spite of slight intestinal affections. The main results were indoor climatic improvements, i.e. temperatures ranging from $14^{\circ} \mathrm{C}$ to $19^{\circ} \mathrm{C}$ and daily temperature variations below $8{ }^{\circ} \mathrm{C}$. No heating or extra insulation were then required. Both systems used pressure ventilation which shows the benefit of such a choice. 